\title{
Penerapan Model Pembelajaran Problem Based Learning terhadap Hasil Belajar Mata Pelajaran Perawatan Wajah, Badan (Body Massage) dan Waxing Siswa
}

\author{
A. A. Oka Santi Suardini*
}

SMK Negeri 2 Singaraja, Buleleng, Indonesia

\begin{abstract}
Abstrak
Penelitian ini bertujuan untuk meningkatkan hasil belajar siswa pada mata pelajaran Perawatan Wajah, Badan (body massage) dan Waxing yang dibelajarkan dengan model pembelajaran Problem based learning di kelas XI Tata Kecantikan 1 Semester Ganjil SMKN 2 Singaraja tahun ajaran 2018/2019.Penelitian ini tergolong penelitian tindakan kelas yang dilaksanakan dalam dua siklus, dengan bentuk guru Keywords:

Problem Based

Learning, hasil belajar, perawatan wajah, badan (body massage), waxing sebagai peneliti.Subyek penelitian yang akan dijadikan penelitian adalah siswa kelas XI Tata Kecantikan 1 Semester ganjil SMK N 2 Singaraja tahun pelajaran 2018/2019 yang berjumlah 35 orang. Data dianalisis menggunakan analisis statistik deskriptif. Hasil analisis data hasil belajar siswa dalam pelajaran perawatan wajah, badan (body massage) dan waxing dengan skor rata-rata hasil belajar siswa yang diperoleh pada siklus I 78,65\% dan menjadi 81,35\% pada siklus ke II dan siklus ketuntasan belajar pada siklus I dan II masing-masing 83,65\% dan 90,30\%..Berdasarkan hasil analisis data dan pembahasan, simpulan penelitian ini adalah penerapan model pembelajaran problem based learning dengan seting belajar kelompok dapat meningkatkan hasil belajar siswa dalam pelajaran perawatan wajah, badan (body massage) dan waxing.
\end{abstract}

\section{PENDAHULUAN}

Zaman sekarang ini dunia kecantikan sudah jauh lebih maju, hal itu dibuktikan dengan banyak dan berkembangnya jenis produk kosmetik kecantikan baik di bidang rambut maupun kulit. Salah satu faktor pendukung berkembangnya produk tersebut karena tingginya selera masyarakat untuk melakukan perubahan-perubahan pada diri mereka secara cepat dan praktis seperti mewarnai rambut, baik tua maupun muda. Oleh karena itu pelajar yang berkualitas dan berasal dari jurusan tata kecantikan sangat dibutuhkan saat ini oleh industri-industri pelayanan jasa, seperti salon, spa, atau pun industry pemijatan. Dan tidak tertutup kemungkinan juga para tamatan tata kecantikan yang memang berkualitas dan mempunyai semangat juang tinggi mampu menciptakan lapangan pekerjaan setelah tamat. Disinilah guru sebagai pendidik sangat berperan penting dalam perkembangan pengetahuan peserta didik. Salah satu yang mempengaruhi rendahnya sumber daya manusia adalah faktor pendidikan. Sistem pendidikan di Indonesia dianggap belum mampu menghasilkan sumber daya manusia yang siap bersaing dengan dunia luar. Sehingga harus ada pembaharuan dalam bidang pendidikan. Peran guru saat ini diarahkan untuk menjadi fasilitator yang dapat membantu siswa dalam belajar, bukan sekedar menyampaikan materi saja. Guru harus mampu melibatkan siswa dalam kegiatan pembelajara secara optimal.

Menurut Rusman (2011) dan (Wawan, 2010), bahwa aktivitas dalam proses belajar mengajar adalah rangkaian kegiatan yang meliputi keaktifan siswa dalam mengikuti pelajaran, bertanya hal yang belum jelas, mencatat, mendengar, berpikir, membaca dan segala kegiatan yang dilakukan yang dapat menunjang prestasi belajar. Hal ini juga seharusnya berlaku untuk kompetensi melakukan pewarnaan rambut. Permasalahan di atas perlu diupayakan penanggulangannya yaitu dengan mengembangkan suatu

* Corresponding author.

E-mail Addresses: - okasantisuardini@gmail.com (A. A. Oka Santi Suardini) 
model pembelajaran yang dapat meningkatkan hasil belajar siswa dan mengupayakan siswa aktif sehingga dalam belajar siswa tidak hanya menerima apa yang disampaikan guru saat proses belajar mengajar berlangsung dan agar siswa dapat memahami konsep pewarnaan rambut yang sebenarnya dan tidak mengalami kesulitan dalam menyelesaikan permasalahan yang ditemukan saaat melaksanakan praktek. Salah satu upaya untuk meningkatkan hasil belajar siswa adalah dengan menerapkan model pembelajaran Problem based learning. Problem based learning sebagai suatu pendekatan yang dipandang dapat memenuhi keperluan ini (Schmidt, dalam Gijselaers, 1996). Masalah-masalah disiapkan sebagai stimulus pembelajaran. Pembelajar dihadapkan pada situasi pemecahan masalah, dan pembelajar hanya berperan memfasilitasi terjadinya proses belajar dan memonitor proses pemecahan masalah.

Model ini juga dikenal dengan nama lain seperti project based teaching, experienced based education, dan anchoredinstruction (Ibrahim dan Nur, 2004). Pembelajaran ini membantu pebelajar belajar isi akademik dan keterampilan memecahkan masalah dengan melibatkan mereka pada sistuasi masalah kehidupan nyata.

Pembelajaran berbasis masalah diturunkan dari teori bahwa belajar adalah proses dimana pembelajar secara aktif mengkontruksi pengetahuan (Gijselaers, 1996). Psikologi kognitif modern menyatakan bahwa belajar terjadi dari aksi pembelajar, dan pengajaran hanya berperan dalam memfasilitasi terjadinya aktivitas kontruksi pengetahuan oleh pembelajar. Pembelajar harus memusatkan perhatiannya untuk membantu pembelajar mencapai keterampilan self directed learning.

Dalam pembelajaran berbasis masalah pebelajar memperoleh pengetahuan ilmiah dalam konteks dimana pengetahuan itu digunakan. Pebelajar akan mempertahankan pengetahuannya dan menerapknanya dengan tepat bila konsep-konsep yang mereka pelajari berkaitan dengan penerapannya. Dengan demikian pembelajar akan menyadari makna dari pengetahuan yang mereka pelajari.

Pembelajaran Problem based learning adalah suatu model pembelajaran yang dirancang untuk mengembangkan kemampuan peserta didik dalam memecahkan suatu masalah. Pembelajaran Problem based learning menuntut siswa untuk dapat memecahkan masalah yang diberikan dengan cara mereka sendiri (Riyanto,2010). Menurut undang-undang RI No. 20 tahun 2003 tentang system pendidikan nasional disebutkan bahwa tujuan pendidikan sekolah menengah kejuruan (SMK) adalah mempersiapkan peserta didik terutama bekerja dalam bidang tertentu.

Pada model pembelajaran Problem based learning berbeda dengan model pembelajaran yang lainnya, dalam model pembelajaran ini, peranan guru adalah menyodorkan berbagai masalah, memberikan pertanyaan, dan memfasilitasi investigasi dan dialog. Guru memberikan kesempatan kepada peserta didik untuk menetapkan topik masalah yang akan dibahas, walaupun sebenarnya guru telah menetapkan topik masalah apa yang harus dibahas. Hal yang paling utama adalah guru menyediakan perancah atau kerangka pendukung yang dapat meningkatkan kemampuan penyelidikan dan intelegensi peserta didik dalam berpikir. Proses pembelajaran diarahkan agar peserta didik mampu menyelesaikan masalah secara sistematis dan logis. Model pembelajaran ini dapat terjadi jika guru dapat menciptakan lingkungan kelas yang terbuka dan jujur, karena kelas itu sendiri merupakan tempat pertukaran ide-ide peserta didik dalam menanggapi berbagai masalah.

SMK Negeri 2 Singaraja sebagai sebuah lembaga pendidikan dan latihan untuk tingkat menengah kejuruan, memiliki tekad menjadi lembaga pendidikan dan latihan tingkat menengah kejuruan yang berorientasi mutu pada semua kegiatannya dalam menghasilkanlulusan yang siap berwirausaha memasuki lapangan kerja baik dalam maupun luar negeri yang memiliki kompetensi dan mengembangkan diri secara profesionalisme serta dapat meneruskan pendidikan

ke jenjang yang lebih tinggi. Demi terwujudnya tekad tersebut SMK Negeri 2 Singaraja membangun visi yaitu mewujudkan SMK Negeri 2 Singaraja sebagai diklat unggul dalam menghasilkan tamatan dibidang Tata Boga, Tata Busana, Tata Kecantikan dan Akomodasi Perhotelan berstandar Internasional dan mampu bersaing dipasar global. Untuk melaksanakan visi tersebut maka SMK Negeri 2 Singaraja mempunyai misi yaitu menyiapkan SDM yang terampil, kreatif dan berwawasan luas sesuai bidang keahliannya dan berorientasi mutu disegala kegiatannya, mengembangkan iklim belajar dan bekerja yang kompetitif dengan pemberdayaan potensi sekolah: Guru, siswa dan masyarakat yang dilandasi oleh kedisiplinan. Dalam pengaplikasiannya penyelesaian permasalahan di temukan dalam proses Perawatan Wajah, badan (body massage) dan waxing, sehingga hal ini ditekankan guna meningkatkan kompetensi siswa untuk berpikir kritis dan sistematis dalam memahami konsep Perawatan Wajah, badan (body massage) dan waxing

Berdasarkan hasil pembelajaran yang sebelumnya sudah dilakukan oleh beberapa guru bidang studi Perawatan Wajah, badan (body massage) dan waxing dan observasi yang dilakukan sebelumnya, dinyatakan bahwa siswa belum mampu menguasai Perawatan Wajah, badan (body massage) dan waxing di SMK Negeri 2 Singaraja siswa cenderung bingung saat dilakukan test lisan maupun tulisan sehingga hal ini mengakibatkan siswa kurang berminat mempelajari kompetensi Perawatan Wajah, badan (body 
massage) dan waxing dan hasil belajar siswa rendah. Hal ini didukung dengan hasil perolehan nilai semester siswa 23 dari 35 siswa (65, 71\% siswa) kelas XI Tata Kecantikan 1 di SMK N 2 Singaraja.

Melakukan Perawatan Wajah, Badan (body massage) dan Waxingmerupakan salah satu kompetensi tata kecantikan rambut yang mempelajari perawatan wajah, perawatan badan dan waxing. Pengetahuan Perawatan Wajah, Badan (body massage) dan Waxingbukanlah kompetensi yang menuntut kemampuan menghafal pelaksanaan Perawatan Wajah, Badan (body massage) dan Waxing(secara teori), selain itu siswa terampil dan berkualitas sesuai dengan bidangnya Lulusan Sekolah Menengah Kejuruan (SMK) jurusan tata kecantikan diharuskan menguasai teori dan praktek sehingga mampu terjun ke dunia industri.

Penelitian ini dikuatkan oleh penelitian yang dilakukan sebelumnya oleh Yunin Nurun Nafiah (2016) Menyatakan penerapan PBL dapat meningkatkan hasil belajar siswa sebesar 31,03\%, dan (d) Hasil belajar siswa setelah penerapan PBL yakni jumlah siswa yang mencapai KKM sebanyak 29 siswa (100\%). Marhamah Salehm (2013) menyatakan model PBL sangat efektif dalam memudahkan pemahaman mahasiswa dan menghubungkan pengetahuan mereka dengan realitas permasalahan yang ada dalam masyarakat. Hal senada juga diungkapkan Rizal Abdurrozak (2016) menyatakan berdasarkan hasil penelitian yang dilakukan terdapat peningkatan kemampuan berpikir kreatif siswa dengan menggunakan model PBL. Amelia Dwi Fitri (2016) juga menyatakan bahwa pembelajaran merupakan sesuatu yang diberikan kontekstual (Learning should be a contextual process).

Pembelajaran problem based learning merupakan salah satu model pembelajaran inovatif yang dapat memberikan kondisi belajar aktif kepada siswa. Pembelajaran problem based learning adalah suatu model pembelajaran yang melibatkan siswa untuk memecahkan suatu masalah melalui tahap-tahap metode ilmiah sehingga siswa dapat mempelajari pengetahuan yang berhubungan dengan masalah tersebut dan sekaligus memiliki keterampilan untuk memecahkan masalah. Model pembelajaran problem based learning juga merupakan suatu model pembelajaran yang didasarkan pada banyaknya permasalahan yang membutuhkan penyelidikan autentik yakni penyelidikan yang membutuhkan penyelesaian nyata dari permasalahan yang nyata. Berdasarkan pengalaman peneliti sebelumnya yaitu Venny (Mahasiswa UNDIKSHA. Jurusan Fisika, 2007) model pembelajaran berbasis masalah memiliki kendala yang bisa membuat hasil penelitian kurang maksimal. Kendala tersebut adalah keterbatasan peneliti dalam mengalokasikan waktu pada saat siswa mengajukan hasil diskusi, sehingga tidak semua kelompok dapat menyajikan hasil diskusi. Kurangnya pengalaman peneliti dalam mengelola kelas sehingga kondisi siswa yang ribut menyebabkan penelitian menjadi kurang efisien. Berdasarkan uraian diatas maka penulis tertarik untuk melakukan suatu penelitian dengan judul "Penerapan Model Pembelajaran Problem Based Learning Terhadap Hasil Belajar Mata Pelajaran Perawatan Wajah, Badan (body massage) dan WaxingSiswa Kelas XI Tata Kecantikan 1 Semester Ganjil SMK Negeri 2 Singaraja tahun Ajaran 2018/ 2019"

Penelitian ini bertujuan untuk meningkatkan hasil belajar siswa pada mata pelajaran Perawatan Wajah, Badan (body massage) dan Waxing yang dibelajarkan dengan model pembelajaran Problem based learning di kelas XI Tata Kecantikan 1 Semester Ganjil SMKN 2 Singaraja tahun ajaran 2018/2019.

\section{METODE PENELITIAN}

Penelitian ini adalah penelitian tindakan kelas (PTK) karena bertujuan memperbaiki kualitas pembelajaran yang bermuara pada peningkatan kualitas kinerja guru dan peningkatan aktivitas serta hasil belajar siswa. "Menurut Arikunto, dkk (2002: 3), menyatakan bahwa, "PTK merupakan suatu pencermatan terhadap kegiatan belajar sebuah tindakan, yang sengaja dimunculkan dan terjadi dalam sebuah kelas secara bersama". Untuk penelitian ini penulis memilih rancangan penelitian tindakan menurut Arikunto, Suharsimi (2005)

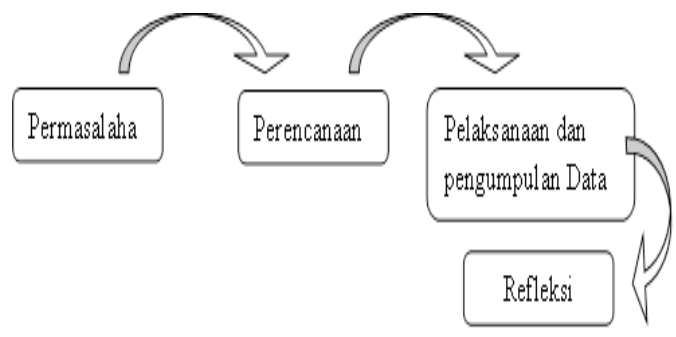

SIKLUS I

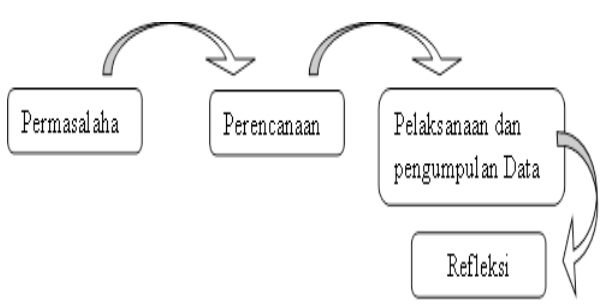

SIKLUS II

Gambar 1. Siklus PTK 


\section{Siklus 1}

a. Perencanaan

Pada tahap ini peneliti membuat RPP dan membuat instrument penilaian. Rancangan dilakukan bersama antara peneliti yang akan melakukan tindakan dengan guru lain akan mengamati proses jalannya tindakan.

b. Pelaksanaan Tindakan

Pelaksanaan tindakan dilakukan dengan pembelajaran di kelas. Pada tahap ini guru peneliti giat melakukan tindakan menggunakan bantuan alat peraga. Rancangan tindakan tersebut sebelumnya telah dilatih untuk dapat diterapkan di dalam kelas sesuai dengan skenarionya. Scenario dari tindakan diupayakan dilaksanakan dengan baik dan wajar

c. Pengamatan atau Observasi

Tahap ini berjalan bersamaan saat pelaksanaan, pengamatan dilakukan pada waktu tindakan sedang berjalan. Pada tahap ini, guru yang bertindak sebagai peneliti melakukan pengamatan dan mencatat semua hal yang diperlukan dan terjadi selama pelaksanaan tindakan berlangsung. Penelitian ini menggunakan jenis observasi partisipasi yaitu observasi yang dilakukan dimana observer ikut serta dalam berbagai kegiatan pihak yang diamati dan segera mencatat apa yang terjadi, termasuk komentar-komentar yang menafsirkan apa yang terjadi berdasarka sudut pandang peneliti (Rochiati Wiriatmadja, 2008: 107). Melalui observasi partisipasi ini, observer terlihat secaara langsung dan lebih mendala dalam suatu penelitian.

d. Refleksi

Tahap ini dimaksudkan untuk menyaji secara menyeluruh tindakan yang telah dibakukan, berdasarkan data yang telah terkumpul, kemudian dilakukan evaluasi guna menyempurnakan tindakan berikutnya. Refleksi dalam PTK mencakup analisis, sintesis dan penilaian terhadap hasil pengamatan atas tindakan yang dilakukan. Jika terdapat masalah dari proses refleksi maka dilakukan proses pengkajisn ulang melalui siklus berikutnya yang meliputi kegiatan: perencanaan ulang, tindakan ulang, dan pengamatan ulang sehingga permasalahan dapat teratasi.

\section{Siklus II}

Seperti halnya siklus pertama, siklus kedua pun terdiri dari perencanaan, pelaksanaan, pengamatan/observasi dan refleksi.

Penelitian ini dilakukan di SMK Negeri 2 Singaraja program studi Tata Kecantikan Kulit dan Rambut. Penelitian ini dilaksanakan pada semester ganjil tahun pelajaran 2018/2019. Subyek penelitian yang akan dijadikan penelitian adalah siswa kelas XI Tata Kecantikan 1Semester ganjil SMK N 2 Singaraja tahun pelajaran 2018/2019 yang berjumlah 35 orang.

Data mengenai hasil belajar siswa yang dikumpulkan pada akhir setiap siklus. Tes hasil belajar ini dilakukan untuk mengetahui sejauh mana keberhasilan tindakan yang dilakukan dalam meningkatkan pemahaman konsep siswa terhadap materi yang diberikan. Instrumen ini disusun oleh peneliti dengan berpedoman terhadap tujuan pengajaran yang telah dirumuskan. Penelitian ini menggunakan análisis statistik deskriptif.

\section{ANALISIS DAN PEMBAHASAN}

Berdasarkan data hasil belajar siklus I diperoleh persentase jumlah siwa yang termasuk kategori sangat baik sebesar 27,78\%. Kategori baik sebesar 33,36\% kategori cukup sebesar 38,89\% dan tidak ada kategori kurang dan sangat kurang. Pada siklus II diperoleh kategori sangat baik sebesar 34,38\%, kategori baik sebesar 55,51\% dan kategori cukup sebesar 10,11\% tidak ada siswa dengan kategori kurang dan sangat kurang.

Berdasarkan hasil analisis pada siklus I. rata-rata hasil belajar 78,65\% dengan kategori baik menjadi 81,35 \%, temuan ini mewujudkan bahwa hasil tersebut telah memenuhi tuntutan yang diharapkan dalam penelitian ini, dari hasil refleksi pada siklus I terdapat kendala-kendala yang menyebabkan belum tercapainya hasil yang diharapkan yaitu: (1) ada beberapa siswa tidak mau berpartisipasi dalam kelompoknya, (2) ada beberapa siswa belum bisa mencari masalah dan berpusat pada masalah yang didapat, (3) banyak siswa mengeluh mereka mengatakan bahwa waktu yang diberikan pada waktu diskusi kelompok terlalu sedikit sehingga banyak permasalahan yang belum terpecahkan, (4) pada saat menyajikan hasil kerja masih banyak siswa yang belum mempersiapkan diri secara maksimal. Berdasarkan kendala-kendala pada siklus I maka pada siklus II dilakukan upaya-upaya perbaikan yaitu : (1) peneliti merubah kelompok pasangan pada saat siswa melakukan praktek sesuaikan dengan kemampuannya (2) sebelum pelaksanaan tindakan siklus II peneliti/ guru mensosialisasikan kembali 
maksud dari pembelajaran problem based learning pada mata pelajaran perawatan wajah, badan (body massage) dan waxing (3) guru / peneliti memberikan arahan kepada siswa agar tidak malu.

Dengan melakukan perbaikan / pemecahan masalah terhadap kendala-kendala yang dihadapi pada siklus I pembelajaran pada siklus II tampak lebih baik dari sebelum pelajaran, Skor prestasi belajarnya meningkat dari sebesar 83,65 dengan kategori baik pada siklus I menjadi sebesar 90, 30 baik pada siklus II.

Secara umum penelitian ini dapat dikatakan berhasil karena beberapa kreteria keberhasilan yang diharapkan dapat tercapai yaitu: (1) Hasil belajar siswa dengan mengunakan model pembelajran berbasis masalah dapat meningkat dengan adanya pengaruh yang besar pada hasil belajar siswa dari siklus I ke siklus II yang memiliki kategori baik. Keberhasilan yang diperoleh dalam penelitian ini disebabkan karena adanya kelebihan-kelebihan yang dimiliki model pembelajaran problem based learning diantaranya : (1) Realistis dengan kehidupan siswa: dimana dalam melakukan proses pembelajaran perawatan wajah, badan (body massage) dan waxing sudah mengetahui masalah-masalah yang mereka dapat, maka dari itu mereka dapat memecahkan masalah itu dengan melakukan praktik-prtaktik selanjutnya (2) Konsep sesuai dengan kebutuhan siswa: karenan sebelumnya siswa pernah mengalami kegagalan saat melakukan pembelajaran pelurusan dan telah mengetahui apa penyebabnya, maka saat melakukan praktek dengan materi yang sama, siswa diharapkan tidak melakukan kegagalan kembali. (3) Memupuk sifat inquiri siswa: dengan pengalaman yang siswa alami, siswa akan memiliki sifat selalu ingin menyelidiki masalah yang ia temukan selama ini dengan selalu mencoba. Dan dengan adanya masalah yang dialami siswa saat melakukan pewarnaan rambut, siswa selalu ingin mencoba kembali melakukan pelurusan rambut dengan jenis rambut, kosmetik dan teknik yang berbeda-beda. (4) Retensi konsep jadi kuat: karena ia yang mengalami langsung masalah tersebut, maka ia meiliki hipotesis yang kuat atas konsepnya tersebut. (5) Memupuk kemampuan problem solving: Selalu ingin mencari tahu terus. Dari praktek-praktek dan masalah-masalah yang ia temukan, maka ia akan selalu mencari ingin mencari tahu, agar ia bisa menghasilkan hasil pewarnaan rambut artistic yang maksimal.

Namun masih ada kelemahan dan kendala yang ditemui dalam penerapan model pembelajaran berbasis Masalah ini yaitu: (1) Membutuhkan persiapan pembelajaran (alat, problem, konsep) yang kompleks: Untuk memecahkan suatu masalah, maka siswa memerlukan alat, problem dan konsep yang jelas. (2) Sulitnya mencari problem yang relevan: Siswa sering sulit mencari probem yang sesuai dengan materi ajar guru. (3) Sering terjadi miss-konsepsi: Sering terjadi kesalahan persepsi (pengertian) terhadap hupotesis yang ia mililki. Ternyadinya kesalahan pengertian antara teknik yang telah diajarkan oleh guru sebelumnya. (4) Memerlukan waktu yang cukup lama dalam proses penyelidikan.

\section{KESIMPULAN}

Berdasarkan hasil analisis data dan pembahasan dapat disimpulkan hal-hal sebagai berikut : Penerapan model pembelajaran problem based learning dengan seting belajar kelompok dapat meningkatkan hasil belajar siswa dalam pelajaran perawatan wajah, badan (body massage) dan waxing dengan skor rata-rata hasil belajar siswa yang diperoleh pada siklus I 78,65\% dan menjadi $81,35 \%$ pada siklus ke II dan siklus ketuntasan belajar pada siklus I dan II masing-masing 83,65\% dan 90,30\%.

Berdasarkan hasil penelitian melalui penerapan model pembelajaran problem based learning dalam pembelajaran Perawatan Wajah, Badan (body massage) dan Waxing terjadi peningkatan hasil belajar siswa, maka disarankan hal-hal sebagai berikut.

1. Kepada guru Tata Kecantikan SMK agar berusaha mencoba menerapkan model pembelajaran pembelajaran problem based learning dalam pembelajaran sebagai upaya untuk meningkatkan hasil belajar siswa.

2. Kepada pembaca, jika berkeinginan mengadakan penelitian lebih lanjut lagi mengenai pembelajaran problem based learning diharapkan mengambil materi lebih. Untuk menyakinkan hasil penelitian ini dan diharapkan mengatasi kendala serta kelemahan-kelemahan yang dihadapi dalam penelitian sehingga hasil yang diperoleh optimal.

\section{DAFTAR PUSTAKA}

Amelia Dwi Fitri. 2016. Penerapan Problem Based Learnin (Pbl) Dalam Kurikulum Berbasis Kompetensi. JAMBI MEDICAL JOURNAL Jurnal Kedokteran dan Kesehatan. Vol 4. No1.

Arikunto, S. 2002. Prosedur Penelitian. Jakarta: Rineka Cipta.

Arikunto, Suharsimi. 2005.Manajemen Penelitian. Jakarta: Rhineka Cipta. 
Marhamah Saleh. 2013. Strategi Pembelajaran Fiqh dengan Problem-Based Learning. Jurnal Ilmiah DIDAKTIKA. VOL. XIV NO. 1, 190-220.

Rizal Abdurrozak, Asep Kurnia Jayadinata, Isrok 'atun. 2016. Pengaruh Model Problem Based Learning Terhadap Kemampuan Berpikir Kreatif Siswa. Jurnal Pena Ilmiah: Vol. 1, No, 1.

Rusman, dkk. 2011. Pembelajaran Berbasis Teknologi Informasi dan Komunikasi. Jakarta: Rajawa;I Pers. PT Raja Grafindo Persada.

Yunin Nurun Nafiah, Wardan Suyanto. 2016. Penerapan Model Problem-Based Learning Untuk Meningkatkan Keterampilan Berpikir Kritis Dan Hasil Belajar Siswa. Jurnal Pendidikan Vokasi UNY. Vol 1 No 2. 